\title{
Specific amplification of iron receptor genes in Xylella fastidiosa strains from different hosts
}

\author{
Flávia Teresa Hansen Pacheco ${ }^{1}$, Maria Estela Silva-Stenico ${ }^{1}$, Augusto Etchegaray ${ }^{1}$, \\ José Elias Gomes ${ }^{1}$, Emanuel Carrilho ${ }^{2}$ and Siu Mui Tsai ${ }^{1}$ \\ ${ }^{1}$ Universidade de São Paulo, Centro de Energia Nuclear na Agricultura, Laboratório de Biologia Celular \\ e Molecular, Piracicaba, SP, Brazil. \\ ${ }^{2}$ Universidade de São Paulo, Instituto de Química de São Carlos, Laboratório de Cromatografia, \\ São Carlos, SP, Brazil.
}

\begin{abstract}
Bacterial production of siderophores may involve specific genes related to nonribosomal peptide and polyketide biosynthesis, which have not been fully identified in the genome of Xylella fastidiosa strain 9a5c. However, a search for siderophore-related genes in strain 9a5c indicated five membrane receptors, including siderophore, ferrichrome-iron and hemin receptors. All these biomolecules are thought to be associated with iron transport and utilization. Eighty isolates obtained from citrus orchards containing trees that developed citrus variegated chlorosis (CVC) were screened for siderophore production. The results demonstrated that only 10 of the isolates did not produce siderophores. Additional strains obtained from coffee, almond, mulberry, elm, ragweed, periwinkle and grape also infected by $X$. fastidiosa were also shown by the chromeazurol bioassay to produce siderophores. In order to correlate siderophore production with the presence of siderophore-related genes, a polymerase chain reaction (PCR) was developed using specific primers for the catechol-type ferric enterobactin receptor (pfeA) and the hydroxamate-type ferrisiderophore receptor (fiuA) genes of strain 9a5c. The PCR results confirmed our hypothesis by demonstrating that amplification products were detected in all strains except for those isolates that did not produce siderophores.
\end{abstract}

Key words: citrus variegated chlorosis, plant pathogen, iron-transportation, pyoverdine, enterobactin, polyketide synthase, peptide synthetase.

Received: July 22, 2004; Accepted: August 1, 2005.

The Gram-negative, xylem-limited bacterium Xylella fastidiosa causes a range of economically important plant diseases, including citrus variegated chlorosis (CVC), Pierce's disease (PD) of grapevine, alfalfa dwarf, leaf scorch of almond, coffee, elm, sycamore, oak, plum, mulberry and maple, and wilt in periwinkle and ragweed (Chang et al., 1993) but the molecular mechanisms through which $X$. fastidiosa establishes the infection process have not yet been fully determined.

The genome of $X$. fastidiosa 9 a 5 c contains 67 genes encoding proteins involved in iron metabolism and has been reported to contain five membrane receptors, including siderophore, ferrichrome-iron and hemin receptors, all of which are thought to be associated with iron transport and utilization (Simpson et al., 2000).

Send correspondence to Flávia Teresa Hansen Pacheco. Universidade de São Paulo, Centro de Energia Nuclear na Agricultura, Laboratório de Biologia Celular e Molecular, Av. Centenário 303 13400-970 Piracicaba, SP, Brazil. E-mail: flapache@hotmail.com.
In microbes, the demand for iron often induces excretion of siderophores, low molar mass metabolites with high affinity for ferric iron (Ankenbauer et al., 1994). Most bacterial siderophores are nonribosomal bioactive peptides synthesized by the multifunctional nonribosomal peptide synthetases (NRPSs) (Kleinkauf and von Doehren, 1996; Etchegaray et al., 2004). Nonribosomal peptide synthetase homologues have been shown to be involved in the biogenesis of siderophore molecules such as yersiniabactin (or yersianiophore), an iron-chelating virulence factor of the human pathogen Yersinia pestis (Gehring et al., 1998a) expressed during iron starvation. There is considerable homology between yersiniabactin synthetase and NRPSs, especially enterobactin synthetase (Gehring et al., 1998b).

Preliminary evidence supporting the putative production of siderophores by $X$. fastidiosa developed by our group (Silva-Stenico et al., 2005) shows that the presence of $X$. fastidios $a$ siderophores is related to iron stress. 
Specific analysis of the genome of $X$. fastidiosa strain $9 \mathrm{a} 5 \mathrm{c}$ for the presence of nonribosomal peptide biosynthetic genes has shown putative NRPS and polyketide synthase (PKS) homologues. Since NRPS and PKS genes can be involved in both siderophore biosynthesis and pathogenicity, we have also investigated these types of genes employing specific primers based on the sequences of the NRPS, PKS and siderophore-receptor genes identified in the genome of strain $9 \mathrm{a} 5 \mathrm{c}$. These results demonstrate a correlation between siderophore production and the presence of genes involved in its transportation and reception by $X$. fastidiosa.

In the study described in the present paper most of the $X$. fastidiosa strains were isolated by us using BCYE (buffered charcoal yeast extract) medium (Wells et al., 1987) from four citrus orchards located in, or near, the towns of Gavião Peixoto, Neves Paulista, Paraíso and Santa Rita do Passa Quatro in the Brazilian state of São Paulo, although some strains were purchased from culture collections or received as a gift from laboratories (Table 1). A total of $80 \mathrm{X}$. fastidiosa strains were used in our study, all strains being maintained on PW (periwinlke wilt) medium (Davis et al., 1981) irrespective of their origin.

To screen for siderophore production by the $80 \mathrm{X}$. fastidiosa strains we developed an agar siderophore production screening test based on the method of Schwyn and Neilands (1987) using PW-CAS (Chromeazurol S) agar prepared as follows: $60.5 \mathrm{mg}$ CAS was dissolved in $50 \mathrm{~mL}$ of ultra-pure water and $10 \mathrm{~mL}$ of iron (III) solution (1 mmol $\mathrm{L}^{-1} \mathrm{FeCl}_{3} \cdot 6 \mathrm{H}_{2} \mathrm{O}$ in $10 \mathrm{mmol} \mathrm{L}^{-1} \mathrm{HCl}$ ) added, the mixture being stirred and slowly mixed with $72.9 \mathrm{mg}$ of hexadecyltrimethylammonium bromide (HDTMA) dissolved in $40 \mathrm{~mL}$ of water, the resultant dark blue solution being autoclaved and then mixed with PW medium. The PWCAS medium was poured into Petri plates which were inoculated with bacteria and incubated at $28^{\circ} \mathrm{C}$ for 15 days. Positive results were indicated by formation of a colorless halo around the colonies. Each assay was performed in triplicate.

Extraction of DNA was performed according to Duningan (1997) and the concentration of DNA estimated by electrophoreses on $0.8 \%(\mathrm{~m} / \mathrm{v})$ agarose gels against known molecular markers, absorbance at 260 and $280 \mathrm{~nm}$ being used to confirm the quality of the DNA. The primers designed for specific sequences are listed in Table 2, appropriate PCR protocols being developed as follows. For the XF599F-599R and XF2134F-2134R primer set the mixture contained $0.1 \mu \mathrm{M}$ of each primer, $0.1 \mu \mathrm{g}$ of extracted $X$. fastidiosa DNA in $10 \mathrm{mM}$ Tris- $\mathrm{HCl}$ (pH 8.3), $50 \mathrm{mM} \mathrm{KCl}$, $1.5 \mathrm{mM} \mathrm{MgCl} 2,20 \mu \mathrm{M}$ of each deoxynucleoside triphosphate and 2.5 units of Taq DNA polymerase in a final volume of $43 \mu \mathrm{L}$. The negative control contained no $X$. fastidiosa DNA. The PCR was initiated by a 4 min denaturation step at $94{ }^{\circ} \mathrm{C}$ followed by 25 cycles at a denaturation temperature of $94{ }^{\circ} \mathrm{C}$ for $1 \mathrm{~min}$, primer annealing at $47^{\circ} \mathrm{C}$ for $1 \mathrm{~min}$ and extension at $72^{\circ} \mathrm{C}$ for $1 \mathrm{~min}$ with a final $5 \mathrm{~min}$ extension. Aliquots $(5 \mu \mathrm{L})$ of the PCR products were visualized on ethidium bromide-stained $1 \%$ agarose gel.

For the XF2135F-2135R and XF2276F-2276R primer set the mixture contained $0.1 \mu \mathrm{M}$ of each primer, $0.1 \mu \mathrm{g}$ of extracted $X$. fastidiosa DNA in $20 \mathrm{mM}$ Tris- $\mathrm{HCl}$ (pH 8.3), $50 \mathrm{mM} \mathrm{KCl}, 20 \mathrm{mM} \mathrm{MgCl}_{2}, 20 \mu \mathrm{M}$ of each deoxynucleoside triphosphate and 2.5 units of Taq DNA polymerase in a final volume of $23 \mu \mathrm{L}$. The negative control contained no $X$. fastidiosa DNA. The PCR started with a 5 min denaturation step at $96^{\circ} \mathrm{C}$ followed by 5 cycles at a denaturation temperature of $95^{\circ} \mathrm{C}$ for $1 \mathrm{~min}$, primer annealing at $45^{\circ} \mathrm{C}$ for $1 \mathrm{~min}$ and extension at $72^{\circ} \mathrm{C}$ for $1 \mathrm{~min}$ followed by another 3 cycles at a denaturation temperature of $95^{\circ} \mathrm{C}$ for $1 \mathrm{~min}$, primer annealing at $45^{\circ} \mathrm{C}$ for $1 \mathrm{~min}$ and extension at $72{ }^{\circ} \mathrm{C}$ for $2.5 \mathrm{~min}$ with a final $5 \mathrm{~min}$ extension. Aliquots $(5 \mu \mathrm{L})$ of the PCR products were visualized on ethidium bromide-stained 1\% agarose gel.

The PCR products were sequenced on an ABI Prism 3100 automatic sequencer with BigDye chemistry (Applied Biosystems, Foster City, California) using about $100 \mathrm{mg}$ of DNA, sample preparation being performed according to the manufacturer's instructions. Sequences were compared to the public database and edited using the Blast 2.0, Align and Clustal W software.

Screening for siderophore production by $X$. fastidiosa can be made by growth on specific media at different iron concentrations. Results demonstrate the effect on the production of new biomolecules in the medium, induced by iron limitation. During this phase, the chemical composition of the medium can be changed and optimized in order to define the most adequate component concentration for siderophore-related gene expression and production.

In our experiments, siderophore production was determined by the formation of an orange/yellow halo around the bacterial colony. Time required for the formation of halos varied amongst the different $X$. fastidiosa isolates tested, isolates from grape presenting halos within 5 to 6 days of inoculation onto PW-CAS agar, while isolates from citrus required about 10 to 12 days before any halo could be detected. We found that the time needed for halos to appear (due to iron uptake) for the different $X$. fastidiosa isolates grown on PW-CAS agar was apparently the same when compared to the period required for the appearance of colonies on PW medium. Nevertheless, a comparative analysis between the $X$. fastidiosa isolates showed that on both PW or PW-CAS agar strains isolated from grape vines showed the fastest and citrus isolates the slowest growth rates.

The tests performed on PW-CAS agar confirmed that 10 of our $X$. fastidiosa isolates do not produced siderophore, suggesting that siderophore producers contain genes involved in siderophore production and transportation or which produce ferri-siderophores and/or proteins probably involved with $X$. fastidiosa pathogenicity. The sizes of the 
Table 1 - Strains of Xylella fastidiosa used in this study.

\begin{tabular}{|c|c|c|c|}
\hline Strain & Biological origin & $\begin{array}{l}\text { Geographic } \\
\text { origin }\end{array}$ & Collection $^{\mathrm{a}}$ \\
\hline \multicolumn{4}{|l|}{ Brazil } \\
\hline $9 \mathrm{a} 5 \mathrm{c}^{*}$ & Citrus sinensis (citrus) & São Paulo & INRA \\
\hline $\mathrm{J} 1 \mathrm{a} 12$ & Citrus sinensis & São Paulo & $\mathrm{CCT}$ \\
\hline $\mathrm{CM}^{*}$ & Coffea arabica (coffee) & São Paulo & $\mathrm{CCT}$ \\
\hline CSR1 & Coffea arabica & São Paulo & $\mathrm{CCT}$ \\
\hline CSR2 & Coffea arabica & São Paulo & $\mathrm{CCT}$ \\
\hline $\mathrm{P} 3 *$ & Coffea arabica & São Paulo & $\mathrm{CCT}$ \\
\hline 6755 & Coffea arabica & São Paulo & $\mathrm{CCT}$ \\
\hline \multicolumn{4}{|l|}{ USA } \\
\hline MUL-1* & Morus nigra (mulberry) & Massachusetts & ATCC 35868 \\
\hline MUL-3* & Morus nigra & Massachusetts & ATCC 35869 \\
\hline ALS-BC* & $\begin{array}{l}\text { Prunus amygdalus } \\
\text { (almond) }\end{array}$ & California & ATCC 35870 \\
\hline ELM-1* & Ulmus americana (elm) & Washington & ATCC 35873 \\
\hline RGW-R & $\begin{array}{l}\text { Ambrosia artimeisiifolia } \\
\text { (ragweed) }\end{array}$ & Florida & ATCC 35876 \\
\hline PWT-22* & Vinca minor (periwinkle) & Florida & ATCC 35878 \\
\hline PCE-GG & Vitis vinifera (grapevine) & California & ATCC 35877 \\
\hline PCE-RR* & Vitis vinifera & Florida & ATCC 35879 \\
\hline PCE-FG & Vitis vinifera & Florida & ATCC 35881 \\
\hline Temecula* & Vitis vinifera & California & ATCC 700964 \\
\hline Fetzer & Vitis vinifera & California & $\mathrm{BC}$ \\
\hline Trever & Vitis vinifera & California & $\mathrm{BC}$ \\
\hline
\end{tabular}

${ }^{\mathrm{a}} \mathrm{INRA}=$ Institut National de la Recherche Agronomique et Université Victor Ségale, Bordeaux, France; CCT = Coleção de Culturas Tropical, Fundação André Tosello, Campinas, Brazil; ATCC = American Type Culture Collection, Manassas, VA, USA; BC = B.C. Kirkpatrick, Department of Plant Pathology, University of California, Davis, California, USA. *Used for sequence analysis.

halos also varied among the $X$. fastidiosa isolates tested with isolates from grapes presented large intensely-colored halos as compared to other strains, possibly due to the fact that these grape isolates grew faster than the citrus isolates. Due to the difficulty in establishing nutritional conditions for microorganisms that induce the production of different siderophore-types or limit their synthesis little is known about the consequences of siderophore production by phytopathogens in plants.

To confirm the presence of the genes involved in iron metabolism or virulence and to assess their potential correlation with pathogenicity we performed PCR analyses of iron metabolism and virulence genes (enterobactin, pyoverdine, NRPS and PKS genes) of $X$. fastidiosa strain 9a5c and the other isolates. The sequences were analyzed using the Sequence Navigator program and were identified by consulting the nucleotide database at the National Center for Biotechnology Information (NCBI, www.ncbi.nlm.nih. gov).

Siderophores belonging to enterobactin-type are produced by a great number of bacteria and are always involved in their pathogenicity. This class of siderophore is found in microorganisms with the capacity to obtain iron from their hosts and has been found in many enteric bacteria, including E. coli and also in other highly pathogenic species such as Yersinia species (enterocolitica, pestis, pseudotuberculosis) and Vibrio cholerae. Another example is the enterobacterium Erwinia chrysanthemi that infects Saintpaulia ionantha and produces the catechol-type siderophore chrysobactin which causes iron deficiency in the leaves of Saintpaulia (Neema et al., 1993).

The amplification of all $X$. fastidiosa isolates presented a single fragment of about 1,600 bp using the primer sets shown in Table 2. The amplification products showed that DNA from citrus, grape, mulberry, almond, periwinkle, ragweed, elm and coffee $X$. fastidiosa isolates have genes potentially involved in the biogenesis of enterobactin-type siderophores.

A single PCR fragment of about $1,000 \mathrm{bp}$ was obtained by amplification using DNA from 70 of our $X$. fastidiosa isolates plus additional strains from coffee, almond, grape, mulberry, ragweed, periwinkle and elm. This fragment indicates that these $X$. fastidiosa isolates have genes responsible for the synthesis of pyoverdine-type siderophores which are known to be associated with the increase of virulence in the host (Cox and Adams, 1985).

Table 2 - Primers based on the specific sequences of Xylella fastidiosa strain 9a5c that were used in this study.

\begin{tabular}{llll}
\hline Primers & 5'-3' Oligonucleotide sequence & GenBank accession numbers & Function (gene or abbreviation) \\
\hline $599 \mathrm{~F}$ & GTC TCA AGA AGG CCT GCA AC & XF0599 & Ferri-pyoverdine TonB receptor $(f p v A)$ \\
$599 \mathrm{R}$ & GTA GTG AAC CCT GCC GAC AT & XF0599 & Ferri-pyoverdine TonB receptor $(f p v A)$ \\
$2134 \mathrm{~F}$ & GAC ATC AGC CAA CAA GAG CA & XF2134 & Ferri-enterobactin receptor $(p f e A)$ \\
$2134 \mathrm{R}$ & GTG ATT GCG TGA GCG ATA GA & XF2134 & Ferri-enterobactin receptor $(p f e A)$ \\
$2135 \mathrm{~F}$ & CAA GAA GTC CTT TTG GAG CG & XF2135 & Polyketide synthase (PKS) \\
$2135 \mathrm{R}$ & TTC AAC TGA GCC AGT GCA TC & XF2135 & Polyketide synthase (PKS) \\
$2276 \mathrm{~F}$ & ACA ATC GTA CAG CAG CAA CG & XF2276 & Non-ribosomal peptide synthetase (NRPS) \\
$2276 \mathrm{R}$ & ACC TGC TCG GTA TAC AAC GG & XF2276 & Non-ribosomal peptide synthetase (NRPS) \\
\hline
\end{tabular}


Table 3 - Screening of Xylella fastidiosa isolates for siderophore and genes associated with iron-uptake (enterobactin, pyoverdine-receptor, polyketide synthase (PKS) and non-ribosomal peptide synthetase (NRPS)).

\begin{tabular}{|c|c|c|c|c|c|c|c|c|c|c|}
\hline \multirow{3}{*}{ Orchards } & \multicolumn{10}{|c|}{ Number of isolates } \\
\hline & \multicolumn{2}{|c|}{$\begin{array}{c}\text { Number of sidero- } \\
\text { phore producers }\end{array}$} & \multicolumn{2}{|c|}{ Enterobactin } & \multicolumn{2}{|c|}{ Pyoverdine } & \multicolumn{2}{|c|}{ NRPS } & \multicolumn{2}{|c|}{ PKS } \\
\hline & Positive & Negative & Positive & Negative & Positive & Negative & Positive & Negative & Positive & Negative \\
\hline S.R. do Passa Quatro & 17 & 3 & 17 & 3 & 18 & 2 & 17 & 3 & 17 & 3 \\
\hline Neves Paulista & 18 & 2 & 9 & 11 & 5 & 15 & 18 & 2 & 18 & 2 \\
\hline Paraíso & 17 & 3 & 14 & 6 & 17 & 3 & 17 & 3 & 17 & 3 \\
\hline Gavião Peixoto & 18 & 2 & 16 & 4 & 15 & 5 & 18 & 2 & 18 & 2 \\
\hline
\end{tabular}

Nonribosomal peptide synthetases (NRPSs) have also been shown to be involved in siderophore production (Gehring et al., 1998a), because of which we selected a set of primers designed to amplify a peptide synthetase based on the related sequence of $X$. fastidiosa strain 9a5c. Homologous non-ribosomal peptide synthetases have been studied for their involvement in the biogenesis of siderophore molecules as an iron chelating virulence factor expressed during iron deficiency. We were able to obtain 560 bp PCR amplification products for 70 of our $X$. fastidiosa isolates. The region amplified is common in genes coding for peptide synthetases and other enzymes such as acetylcoenzyme A synthetase that hydrolyze ATP to activate substrates such as amino acids, carboxylic acids and hydroxy acids. Such enzymatic activities are found in the open reading frames of $X$. fastidiosa strain 9a5c, i.e. the XF287, XF2255 and XF2276 ligases. We calculated the specificity of these ligases and specific amino acids, and our results indicated that, hypothetically, the XF287 ligase is specific for amino acids (Etchegaray et al., 2004). Even so, these results need to be confirmed by the expression of these ligases in E. coli and their full biochemical characterization. It is also important to study the expression of adjacent ORFs, because most of the biosynthesis of non-ribosomal peptides usually requires the support of correlated enzymes (Keinkauf and Von Döhren 1996). These regions will be our targets for future site-directed mutagenesis studies involving the estimation of siderophore production using PW-CAS agar.

A single fragment of about $300 \mathrm{bp}$ was also obtained during the PCR amplification of 70 of our $X$. fastidiosa isolates and for the additional strains isolated from citrus, grape, coffee, almond, mulberry, periwinkle, elm and ragweed. This indicates that all of these isolates contained genome regions encoding sequences homologous to the PKS gene of $X$. fastidiosa strain 9a5c.

Our PCR study was performed in order to screen some $X$. fastidiosa isolates recovered from trees infected with citrus variegated chlorosis for specific genes that may be involved in pathogenicity. In this study we have shown that $X$. fastidiosa isolates from citrus, coffee, grape, almond, elm, mulberry, ragweed and periwinkle produce enterobactin pyoverdine type siderophores and also carry genes related to nonribosomal peptide synthetases and polyketide synthase (Table 3 ). We believe that the ability of $X$. fastidiosa isolates to produce siderophores and absorb iron from its hosts could be involved in pathogenicity.

\section{Acknowledgments}

We thank F.R.S. Duarte for technical assistance during plant sampling. This study was supported by grants 99/07748-1 and 00/08045-3 from the Brazilian agency Fundação de Amparo à Pesquisa do Estado de São Paulo (FAPESP).

\section{References}

Ankenbauer R, Skiyosachati S and Cox CD (1994) Effects of siderophores on the Pseudomonas aeruginosa in human serum and transferrin. Infect Immun 49:132-140.

Chang CJ, Garnier M, Zreik L, Rosseti V and Bové JM (1993) Culture and serological detection of Xylella fastidiosa, the xylem-limited bacterium associated with citrus variegated chlorosis disease. Current Microb 27:137-142.

Cox CD and Adams P (1985) Siderophore activity of pyoverdine for Pseudomonas aeruginosa. Infect Immun 48:130-138.

Davis MJ, French WJ and Schaad NW (1981) Axenic culture of the bacteria associated with phony disease of peach and plum leaf scald. Current Microb 6:309-310.

Dunigan DD (1997) Preparations of genomic DNA from bacteria. Current Prot Molec Biol 241-242.

Etchegaray A, Silva-Stenico ME, Moon DH and Tsai SM (2004) In silico analysis of the nonribosomal peptide synthetases of Xanthomonas axonopodis pv. citri: Identification of putative siderophore and lipopeptide biosynthetic genes. Microbiological Research 159:425-437.

Gehring AM, DeMoll G, Fetherston JD, Mori I, Mayhew GF, Blattner FR, Walsh CT and Perry RD (1998a) Iron acquisition in plague: Modular logic in enzymatic biogenesis of yersiniabactin by Yersinia pestis. Chemistry Biology 5:573-586.

Gehring AM, Mori I, Perry RD and Walsh CT (1998b) The nonribosomal peptide synthetase HMWP2 forms a thiazoline ring during biogenesis of yersiniabactin, an iron-chelating virulence factor of Yersinia pestis. Biochemistry 37:11637-11650. 
Kleinkauf H and von Dohren H (1996) A nonribosomal system of peptide biosynthesis. Europ J Biochem 236:334-351.

Neema C, Laulhére J-P and Expert D (1993) Iron deficiency induced by chrysobactin in Saintpaulia ionantha leaves inoculated with Erwinia chrysanthemi. Plant Physiol 102:967-973.

Schwyn B and Neilands JB (1987) Universal chemical-assay for the detection and determination of siderophores. Anal Biochem 160:47-56.

Silva-Stenico ME, Pacheco FTH, Rodrigues JLM and Tsai SM (2005) Growth and siderophore production of Xylella fastidiosa under iron-limited condition. Microb Res 160:429-436.

Simpson AJ, Reinach FC, Arruda P, Abreu FA, Acencio M, Alvarenga R, Alves LM, Araya JE, Baia GS, Baptista CS, Barros MH, Bonaccorsi ED, Bordin S, Bove JM, Briones MR, Bueno MR, Camargo AA, Camargo LE, Carraro DM, Carrer H, Colauto NB, Colombo C, Costa FF, Costa MC, Costa-Neto CM, Coutinho LL, Cristofani M, Dias-Neto E, Docena C, El-Dorry H, Facincani AP, Ferreira AJ, Ferreira VC, Ferro JA, Fraga JS, Franca SC, Franco MC, Frohme M, Furlan LR, Garnier M, Goldman GH, Goldman MH, Gomes SL, Gruber A, Ho PL, Hoheisel JD, Junqueira ML, Kemper
EL, Kitajima JP, Krieger JE, Kuramae EE, Laigret F, Lambais MR, Leite LC, Lemos EG, Lemos MV, Lopes SA, Lopes CR, Machado JA, Machado MA, Madeira AM, Madeira HM, Marino CL, Marques MV, Martins EA, Martins EM, Matsukuma AY, Menck CF, Miracca EC, Miyaki CY, Monteriro-Vitorello CB, Moon DH, Nagai MA, Nascimento AL, Netto LE, Nhani A Jr, Nobrega FG, Nunes LR, Oliveira MA, de Oliveira MC, de Oliveira RC, Palmieri DA, Paris A, Peixoto BR, Pereira GA, Pereira HA Jr, Pesquero JB, Quaggio RB, Roberto PG, Rodrigues V, de M Rosa AJ, de Rosa VE Jr, de Sa RG, Santelli RV, Sawasaki HE, da Silva AC, da Silva AM, da Silva FR, da Silva WA Jr, da Silveira JF, Silvestri ML, Siqueira WJ, de Souza AA, de Souza AP, Terenzi MF, Truffi D, Tsai SM, Tsuhako MH, Vallada H, Van Sluys MA, Verjovski-Almeida S, Vettore AL, Zago MA, Zatz M, Meidanis J, Setubal JC (2000) The genome sequence of the plant pathogen Xylella fastidiosa. Nature 406:151-157.

Wells JM, Raju BC, Hung HH, Weisburg WG, Mandelco-Paul L and Brennere DJ (1987) Xylella fastidiosa ge. nov., sp. nov.: Gram-negative, xylem-limited, fastidious plant bacteria related to Xanthomonas spp. Int J Syst Bacteriol 37:136-143. Associate Editor: Darcy Fontoura de Almeida 